\title{
LOS ESCRITOS DE BALBOA DE MORGOVEJO Y FRAY PEDRO DE LA MADRE DE DIOS EN SU ESPADA POR SANTIAGO DE QUEVEDO
}

Tras el Memorial por el patronato de Santiago, terminado en enero de 1628, o mientras lo hacía, Quevedo debió de pergeñar un nuevo discurso más amplio de contestación a los distintos papeles. Su espada por Santiago constituye en este sentido, aunque no del todo, un escrito de respuesta a dos de los papeles más importantes de los carmelitas: el de Balboa de Morgovejo ${ }^{1}$ y el de fray Pedro de la Madre de Dios ${ }^{2}$. Quevedo lo recordaba así al final de su Memorial, cuando citaba el Cauterio de la verdad, y sólo un poco más tarde en la carta que envía al cabildo de Santiago el 1 de febrero de 1628 en el que se lo recuerda: "este memorial sirve de prólogo y va a hacer lugar a otro de mayor volumen que estoy escribiendo contra todos los papeles antiguos y modernos que se han impreso en esta razón por este compatronato"3.

El obispo de Coria, en carta del 3 de agosto de 1628, animó a Quevedo - quien ya había enviado al Conde-Duque el texto de $S u$ espada por Santiago-, a no cejar en su empeño: "no me huelgo poco de que vuesa merced prosiga lo comenzado y que el Cauterio de la verdad no quede en olvido, por mucho que hagan esos padres que defienden a capa y espada que no salga a luz"4. Resulta difícil entender

${ }^{1}$ Por la sagrada religión de los carmelitas descalzos con la santa Iglesia metropolitana de Santiago y demás consortes sobre el Patronazgo destos reinos de Castilla que a instancia de su majestad concedió la santidad de nuestro santísimo padre Urbano VIII. El doctor Balboa de Mogrobejo. Cito por el ejemplar que consulté en la Hispanic Society of America, sobre Papeles varios sobre santa Teresa y su patronato [signatura V20]: en lo sucesivo consignaré la página. Utilizo el nombre de Morgovejo por ser el mayoritario en los textos consultados, pero la vacilación es muy frecuente.

${ }^{2}$ Memorial que dio a su majestad el padre fray Pedro de la Madre de Dios. Cito por el ejemplar que consulté en la Hispanic Society of America, sobre Papeles varios sobre santa Teresa y su patronato [signatura V20]: en lo sucesivo consignaré la página.

${ }^{3}$ Cito por el original que se halla en el archivo catedralicio de Santiago. Modernizo las grafías como en el resto de los casos.

${ }^{4}$ Luis Astrana Marín (ed.), Epistolario completo de Francisco de Quevedo, Reus, Madrid, 1946, p. 204. 
si el obispo conocía el nuevo texto quevediano. No olvidemos que ya Juan Ruiz Calderón, en una carta fechada el 1 de agosto de 1628, comenta a Quevedo que el escrito Su espada por Santiago, como antes le había dicho don Álvaro de Villegas, no contaba con el beneplácito del Conde-Duque, porque pretendía que los miembros del Consejo actuaran en el conflicto: "El intento de echar a vuesamerced dél no fue más de parecer que resolvieron el Conde y Villegas, pareciéndoles no había otro remedio para que vuesamerced no escribiese, habiendo tantas ocasiones sobre qué. Y para esto armaron por causa decir que vuesamerced en su libro había hecho a los del Consejo Real tutores de la ley"5. Se está refiriendo a la dedicatoria del Memorial, pero en Su espada por Santiago la petición para que intervenga el Consejo es aún más clara.

En todo caso, el texto de Quevedo parece obedecer al intento de contestar de modo esencial a estos dos documentos: al de Balboa, con razones básicamente jurídicas, y al de fray Pedro, con razones de toda índole, que Quevedo reduce a piadosas y políticas. Entre estas últimas caben las de orden histórico, filológico, teológico incluso, y también las jurídicas, aunque este extremo, tal vez por el escaso valor que otorga Quevedo a su interlocutor en este terreno, está menos desarrollado. De hecho, Quevedo divide Su espada por Santiago en varios tratados. Dedica el tercero a la "respuesta del doctor Balboa del año pasado al doctor Balboa deste año"; y divide el cuarto en dos apartados: uno, para refutar las suposiciones jurídicas de Balboa, y otro, para rebatir las suposiciones políticas y piadosas de fray Pedro. Y en los restantes, como complemento a sus ataques a otros escritos, ambos autores aparecen de modo ocasional, como si esta información en derecho (así creo que se puede llamar el género al que adscribir este discurso quevediano) estuviera concebida no para defender a Santiago sino para dar combate a los autores que defienden a santa Teresa.

El DOCTOR BALbOA Y LAS RAZONES JURÍDICAS

Las referencias a Balboa ya aparecen en el primer tratado, con una cita que pone en cuestión uno de los temas principales del debate: el carácter jurídico o político de la polémica. El doctor Balboa aduce, al comienzo de su escrito, en el número 8 de su información, un pasaje de los Anales de Tácito en el que se rechaza la pretensión de los santiaguistas de poner por delante las razones de Estado como justificación para mantener el patronato único: "todo lo quieren reducir a unas razones de Estado y conveniencia que después de hecha y confirmada esta elección no se deben admitir en juicio. Esto es lo

5 Ibid., p. 203. 
que suelen alegar los que tienen mal pleito, como hacía Nerón y lo refiere Tácito, Annalium 5" (p. 5).

Balboa de Morgovejo, desde el mismo comienzo de su exposición, quiere llevar el asunto a un terreno estrictamente jurídico y por ello rechaza cualquier motivación política. Resulta curioso, e incluso muy significativo dentro del propio ardor polemista, que Quevedo recurra a la misma cita con el objetivo de ser escuchado por el rey y no ser sometida la decisión a las razones de fuerza política que se intuyen tras las acciones de los carmelitas 6 :

Aquí viene a propósito el texto de Tácito en Nerón que el doctor Balboa nos aplica a nosotros: núm 8: Taciti Annal. 5. "Igitur non crimine, non acusatione existente quia spetiem iudiciis induere non poterat ad vim dominationis conuersus". Los padres, Señor, son los que se vuelven a la fuerza de la dominación y del poderío: pues en caso tan grave y tan nuevo quieren que deis espanto, no sentencia.

El tratado segundo, dedicado a ensalzar los méritos de santa Teresa, parece paso obligado por los recelos manifestados por Balboa en su escrito. Quevedo así lo declara:

Esta confesión es tan justo hacerla que por la notoriedad de las maravillas fuera culpable por superflua, si no la ocasionaran los escritos del

${ }^{6}$ Es conocida la participación del Conde-Duque en la defensa del patronato de santa Teresa. Una carta de don Mauricio de Alcedo, fechada el 24 de enero de 1629, que he podido leer en la biblioteca de la Hispanic Society of America, en la que relata una audiencia con el Conde-Duque y en la que curiosamente se nombra a don Francisco de Quevedo, muestra claramente sus preferencias: "El conde duque les recibió con todo el despego posible según me dijo él mismo y con mucha aspereza les dijo que a qué venían a inquietar la pura devoción de su majestad, que esta era tema que no se cansasen que santa Teresa patrocinaba a España y que su majestad la amaba tanto que, a pesar de cuantos hubiese, había de salir patrona, que estaba empeñado en ello desde el buen suceso que alcanzó de diez en la jornada de Brasil y en las instrucciones que llevaban los embajadores, la primera era el despacho de este negocio, que no se cansasen que había de serlo aunque lo estorbase todo el mundo. «Véanla allí», les dijo, «la tengo en frente de mí y cada día la rezo y no cesaré de diligenciarlo hasta que la vea aclamada patrona». Con esto salieron desesperados de entender tendrían efecto sus diligencias. Y con todo eso habían intentado un camino que era disuadir a su majestad por medio del infante arzobispo a quien dieron otro memorial y les mostró buen rostro y que como Coloma el que asiste a la congregación por Toledo es de su cámara por esta vía procuraran apartar a su majestad de este intento: díjome que un no sé quién había hecho un memorial a este propósito y que le había hecho imprimir aquí y que no le habían dado licencia y que debajo de cuerda se había de imprimir ahí. Dígolo para si se pudiera estorbar. De éste se sacaron tres copias: una para su majestad, otra para el infante y otra para el señor conde duque y no otra alguna. Quisiera que hubiera sido mucho antes, mas cierto que no ha sido posible. Lo que suplico a vuestra Presidencia es me mande que no habrá en el mundo criado que con mayor voluntad le sirva. Don Francisco de Quevedo está aquí que dicen le ha enviado a llamar el Presidente". 
doctor Balboa, número 83. "Pues ¿por qué no hemos de dudar si Santa Teresa merece el nombre de Patrona o no? Esta duda indigna es de ponerse en ningún tribunal de justicia”. Dice verdad el doctor Balboa, mas dice poco, que esta duda no sólo es indigna, sino delincuente: no es duda, sino desvergüenza de mala casta y que tiene parentesco con error y con la impiedad.

En este apartado, Quevedo comienza a utilizar las palabras de Balboa de forma parcial, al hurtar a los lectores algunos matices del texto con el fin, lógico y obvio, de desacreditarle. El texto de Balboa añade a la frase citada por Quevedo: "indigna de proponerse a los ojos de la Majestad Católica" (p. 32) cuando acusa a los contrarios de pretender que santa Teresa no es "digna deste nombre honorífico en la tierra, de que tanta gloria redunda a nuestra religión" (p. 3). Quevedo usurpa al debate las palabras completas de Balboa, como hará más adelante cuando refiera el texto de Balboa sin el significativo añadido de quod absurdissimum est: "porque aunque confesáramos una cosa tan ajena de razón, como las partes contrarias alegan, y en que se fundan, videlicet que esta prerrogativa que su majestad concedió a santa Teresa y su santidad confirmó fuera perjudicial a la república (quod absurdissimum est)". El texto de Balboa refuta las frases del arzobispo de Santiago, pero al citarlas para la refutación, en forma de concessio, pretende conferirles un sentido negativo: "Y demos caso, como las partes contrarias alegan, aunque contra toda razón, que su Majestad con este nombre de Patrona de Castilla excedió y la dio más de lo que merecía como en su memorial dice el señor arzobispo de Santiago". Quevedo, como niega que las haya escrito el arzobispo, se las achaca a Balboa, quien, por otra parte, es perfectamente consciente de tal riesgo. Quevedo evita las matizaciones de Balboa con el fin de aprovecharse de expresiones no del todo apropiadas: "Señor, llamar a la Santa indigna y que no merece no son palabras, son delitos", dirá Quevedo. Sin embargo, se olvida de añadir lo que Balboa en su escrito señala: "si bien lo cierto es que no hay honras de la tierra que igualen sus merecimientos" (p. 11).

Es en el tratado tercero donde Quevedo dedica su argumentación a combatir la de Balboa de Morgovejo precisamente con los mismos argumentos que Balboa había empleado un año antes en otro informe jurídico en defensa de los jesuitas. Comienza con la acusación de prevaricación a Balboa de Morgovejo por ser capaz de cambiar de opinión según las circunstancias. Bajo esta premisa, Quevedo dará repaso a algunas consideraciones de Balboa, centrales en la polémica que protagonizan. La primera, que nace también de las primeras palabras de Balboa, es la opinión jurídica de que las decisiones de los reyes son irrevocables. Quevedo recoge varios pasajes en los que Balboa asume esa posición, basada en la libre determinación de los 
monarcas y, por tanto, en el carácter estrictamente voluntario de la decisión. Quevedo, en la primera cita de Balboa, suprime una matización interesante - “en el número 4 al fin: «Y bastaba sola la real voluntad de Vuestra Majestad que este caso no depende del consentimiento de nadie»-, ya que Balboa añadía con mayor precisión: «ni del reino, que no es agravio de los más santos españoles, ni mucho menos de vuestro gran apóstol y patrón Santiago, sino mayor gloria y veneración»" (p. 4). Quevedo transcribirá justo después el punto 7 para que se vea con toda claridad la nueva posición del doctor Balboa, partidario de que el reino y el rey defiendan, y no enmienden, su resolución de otorgar el patronazgo a santa Teresa:

Esta defensa, que pretendemos toca de lleno en lleno a su Majestad y al propio reino en cortes, que son los que principalmente la deben defender. Lo primero, porque su Majestad y el reino hicieron elección de nuestra Santa para Patrona, porque ella intercediese por ellos a Dios y esta elección la confirma su Majestad después de muchas consultas. De que resulta que a la grandeza y autoridad de la Majestad católica pertenece la firmeza de sus acciones.

"La confirma" transcribe Quevedo; "la confirmó" escribe Balboa. ¿Un error de transcripción o una expresión convenientemente trastrocada? En cualquier caso, Quevedo aduce varias muestras de la información por la religión carmelita en las que el catedrático de prima de Salamanca repetirá, con acarreo de autoridades como el Baldo ${ }^{7}$, la imposibilidad de que el rey revoque decisiones propias, mientras las va cotejando y confrontando con sentencias contrarias, escritas por Balboa a propósito de un pleito anterior con los jesuitas.

Donde se puede comprender el modo de diatriba quevediana es en el aprovechamiento de las citas del contrario tomadas de modo parcial. Quevedo contrapone: "El doctor deste año dice en el número 12 "porque este texto y el capítulo quanto De censibus por ningún caso permiten que el príncipe pueda revocar el previlegio y gracia hecha a la Iglesia, cuanto más a este o al otro Santo»", pero el doctor Balboa ya permitía, con técnicas de concesión retórica, la refutación quevediana, quien se aprovecha de la debilidad mostrada:

Tum etiam, porque el cap. sugestum de decimis, aunque diéramos que en este caso concurrieran sus circunstancias, que no concurren, no era aplicable a este pleito, porque este texto y el capítulo quanto de censibus por ningún caso permiten que el príncipe pueda revocar el privilegio y

7 han de ser irrevocables: Balboa de Morgovejo afirma: "es bien sabido al propósito el consejo de Baldo 327, que no sólo habla de la justicia sino también de la conveniencia que tiene el guardar los príncipes soberanos inviolablemente sus concesiones" (Por la sagrada religión, p. 5) 
gracia hecho a la iglesia, cuanto y más a este o el otro santo, porque una vez hechos ya no está en su mano el revocarlos, porque esto puramente pertenece al Pontífice.

La mención al pontífice desaparece en el texto transcrito por Quevedo ya que en la pretensión de los santiaguistas de que sea el rey el que impida la situación, las palabras del pontífice no son necesarias. Quevedo denuncia el doble rasero argumentativo del doctor Balboa, sin entrar al debate de fondo, que encuentra resuelto con las palabras de Balboa. Introduce, sin embargo, a fray Pedro en la refutación porque comprueba que tanto Balboa como el fraile insisten en lo irrevocable de la decisión adoptada ${ }^{8}$.

Quevedo dará un paso más en su argumentación jurídica, con el circunstancial desdoro de la pretensión de Balboa de procurar una cátedra más apetecible, que podría contar en el fondo de su exhibición expositiva $^{9}$. Balboa pretendía circunscribir la polémica al ámbito puramente judicial, al tratarla como pleito entre partes; por eso, critica el empleo de autoridades eclesiásticas para la defensa de Santiago: "las razones que para fundar esto se alegan de parte de Santiago son ajenas de un pleito entre partes, fundadas en lugares de la Escritura entendidos alegóricamente y como consideraciones del púlpito". Quevedo le reprocha este rechazo, habida cuenta de la relación de autoridades bíblicas y eclesiásticas que Balboa incorpora en su pasada defensa de los jesuitas. Quevedo no aporta más novedad que la revisión de lo que Balboa sostenía el año pasado frente a lo que sostiene éste. Quevedo parece no atreverse a debatir el fondo de la cuestión desde un punto de vista estrictamente jurídico y decide llevarlo a un terreno más familiar para el Quevedo filólogo como la glosa de Séneca ${ }^{10}$ o de Valerio Máximo ${ }^{11}$.

8 Fray Pedro observa esto como una batalla: "sosegada la turbación de algunos, fue fácil la victoria de la piedad con que hoy está acabado y la santa en posesión de patrona. Esto no es haber caído, sino seguro de que no caerá" (Memorial que dio a su majestad, f. 14).

${ }^{9}$ Quevedo insinúa que su escrito tiene que ver con preocupaciones académicas: "porque como catedrático de prima puede ser interesado en la falta de los oyentes y del concurso que teme".

${ }^{10}$ Ante las posibles críticas que el uso de la autoridad de Séneca pueda suscitar entre los juriconsultos Quevedo escribirá: "Y si dijere el doctor Balboa y gritare la unida comunidad de los padres de la reforma que esta no es ley, que Séneca no es jurisconsulto, que va mucho de digestis a libro y de capítulo a párrafo, digo, Señor, que Séneca escribió la fuerza de la razón y con las mejores razones; y que la razón y la verdad no es ley: antes las precede y las prefiere, porque es alma de las leyes y el derecho por quien los derechos son. No es Séneca jurisprudente de pleitos, ni de estilo forense y litigioso, mas eslo, y el primero, en el irrefragable conocimiento de la justificación y disposición de las costumbres".

11 "Pondere esto el suceso en semejantes casos tocantes a religión; oíd, Señor, lo que refiere Valerio Máximo li. 4 tit. de Religione neglecta, De la religión despreciada”. 
Sí lo hará en el tratado siguiente, y de forma bien expresa, aunque, como veremos, no siempre con la solidez argumentativa necesaria. El arranque de esa decisión está motivado por la conclusión de Balboa, que Quevedo transcribe de modo incompleto, de que "su Majestad, y lo mismo diremos del reino, está obligado a conservar esta elección, pues en pago della quedó Santa Teresa obligada a rogar a Dios por estos reinos, y mientras ella no faltare a su obligación, no puede faltar su Majestad a la suya, ni en justicia, ni en conciencia”. La cita exacta de Balboa especifica más los términos de esta obligación: "está obligado (porque asi lo quiso) en fuerza de pacto y contrato recíproco" (p. 6; las cursivas son mías). Las referencias de autoridades remiten al Digesta Iustiniani, al capítulo de actionibus empti et venditi (19.1); aunque también figura otro capítulo homónimo en el propio Codex Iustiniani $(4,49)$, en el que aparecen los pasajes de Juliano y que fueron comentados por Bartolo de Sassoferrato, el célebre Bártulo. En este número que Quevedo comenta, Balboa introduce una buena cantidad de autoridades sobre los contratos recíprocos, muchos de ellos, como señala Quevedo, "irrefragables en la materia de contratos y que no los pretendemos negar, antes valernos dellos". Quevedo en este terreno se aferra a una de las ideas que comparte (por no decir que asume) con el arzobispo de Santiago: esto es, que el contrato del rey con la santa está viciado de antemano porque le ha dado algo que no era suyo ni tenía potestad de darle: "si yo contrato con otro y le obligo lo que no es mío y es ajeno y no puedo y debo obligar, que antes cometo estelionato ${ }^{12}$ que celebro pacto o contrato. No se puede dudar esto ni responder". No sólo coincide con el arzobispo de Santiago. La defensa, por ejemplo, del canónigo lectoral de la Iglesia de Santiago, Inquisidor, además, del Reino de Galicia, Benito Méndez de Parga y Andrade en su Respuesta a un papel que escribió el doctor Balboa se desarrolla en semejantes términos. Para el canónigo no hay contrato, sino donación; y además sostiene que, siendo el patronato de Santiago una donación remuneratoria, los príncipes no pueden revocarla:

¿dónde consta que el rey la haya hecho? Y si la hizo el Reino, dio lo que no tenía, porque si el apóstol Santiago era único patrón de España, dende tiempo que memoria de hombres no hay en contrario, por causas justísimas que referimos, ¿qué parte fue el reino para introducir este nuevo patronazgo?... Llano está que hacer uno donación de lo ajeno es como si no diese nada ${ }^{13}$.

$12 \mathrm{El}$ estelionato es un "término forense: delito que comete el que maliciosamente defrauda a otro, encubriendo en el contrato la obligación que sobre la hacienda o alhaja que vende tiene hecha antecedentemente y también si le defrauda alterando y viciando la misma alhaja que vende o empeña y al tiempo de la venta o empeño encubre el dolo y engaño" (Dicc. Aut.).

${ }^{13}$ Respuesta a un papel que escribió el doctor Balboa de Mogrovejo. Doctor Benito Méndez de Andrade, canónigo lectoral en su apostólica iglesia, Inquisidor del reino de Galicia, Im- 
Quevedo prende este discurso con autoridades fácilmente rastreables en el Corpus iuris, sin necesidad, como hace el doctor Balboa, de recurrir a jurisconsultos. Los apartados sobre donaciones, actos jurídicos o pactos, de consulta probablemente sencilla en cualquier volumen del corpus jurídico, se dirigen en Quevedo a sostener la máxima básica de que el rey puede (y debe, por tanto) revocar lo hecho al respecto. Quevedo asumirá como propio argumento probatorio, ya desarrollado en el Memorial por el patronato de Santiago, la idea de "que el Reino y sus procuradores no son parte para dar ni votar este Patronato, por falta de potestad y por contravenir a la cláusula de la bula". La nulidad del proceso es propósito esencial en sus argumentaciones, presente ya en el Memorial por el patronato de Santiago, aunque ahora contra Balboa:

digo que cosa es sabida y cierta y fuera de disputa que los procuradores que las ciudades envían a las cortes vienen con poderes limitados consultivos para tratar aquellas cosas a que se convocan y que si resolviesen alguna fuera de aquellas que expresa su poder, sería nulidad ${ }^{14}$.

Quevedo, pues, rechaza de todo el extenso discurso de Balboa de Morgovejo la idea central de que el rey no puede revocar lo hecho. El discurso presenta numerosas y complejas argumentaciones, todas ellas basadas en abundante erudición jurídica. Da la impresión de que Quevedo no quiso abordar por extenso el conjunto del discurso, quizá excesivamente prolijo y riguroso para poder rebatirlo. Se limitó a contraponerle la opinión que había manifestado un año antes Balboa, a propósito de otro pleito en el que sí era del parecer de permitir al rey cambiar de criterio. $\mathrm{Y}$ a repetir los argumentos conocidos, expuestos ya por el arzobispo de Santiago y reiterados por el coro de defensores del patronato único, sobre la nulidad formal de todo el proceso, por nacer de forma espuria con el acuerdo de los procuradores, incapacitados para tal decisión ${ }^{15}$. "Subrepticia" dirá el arzobis-

prenta de Juan Guixard de León, Santiago, 1628, p. 13. Cito por el ejemplar que consulté en la Hispanic Society of America, sobre Papeles varios sobre santa Teresa y su patronato [signatura V20].

${ }^{14}$ En el Memorial por el patronato de Santiago ya había escrito: “¿Será lícito que el agradecimiento que con los demás apóstoles conservan con menos beneficios las otras naciones, así bárbaras como mezcladas con la herejía, falte a España, debiéndose toda al apóstol Santiago y teniendo el apóstol ejecutoriado por Cristo este patronazgo y esta tutela, y no teniendo los procuradores de Cortes poderes de las ciudades para tratar lo que determinaron?”.

${ }^{15}$ Quevedo rebatirá así a buena parte de sus adversarios, en concreto a Francisco de la Cueva y Silva, autor de una información en derecho titulada "Sobre el título de Patrona destos Reynos, dado a la gloriosa Santa Teresa de Iesus, fundando la elección que los Procuradores de Cortes hizieron. Y respondiendo a todas las oposiciones contrarias". 
po de Santiago; "subrepticiamente" repetirá Quevedo y con ello conformará la respuesta.

\section{Fray Pedro de la Madre de Dios y las razones piadosas y políticas}

El escrito de fray Pedro ofrece material abundante para la diatriba. En el Memorial por el patronato apenas pudo rebatirlo, pero en Su espada por Santiago se extiende con especial cuidado. Probablemente Quevedo viera en su texto más grietas y, sobre todo, expresiones descuidadas que le permitieran acusaciones más eficaces. El texto de Balboa era más técnico; el del fraile carmelita, más literario, salpicado de consideraciones coloquiales que muy fácilmente podrían ser motivo del comentario jocoso e incluso delator. Por ello, Quevedo fue punto por punto mostrando esos flancos débiles, fruto más bien de una imprudente redacción que de cuestiones profundas: a mi juicio, el Quevedo filólogo encuentra en este texto más posibilidades de éxito dialéctico. Quevedo era plenamente consciente de la escasa entidad discursiva del texto de fray Pedro y dirá, con tono de suficiencia: "las suposiciones piadosas y políticas (no sé si encargo la conciencia en llamarlas así) todas abultan, y crecen las planas del memorial que dio a Vuestra Majestad el padre fray Pedro de la Madre de Dios. Ellas son muchas pero son tales que, sin aguardar respuesta juntamente, las más se deletrean y se refutan. Esto antes es agradecimiento que quejas".

Tres son, a mi juicio, los niveles en los que Quevedo establece la refutación del fraile carmelita: el primero, con la crítica de los términos impropios con los que fray Pedro elogia a la santa; el segundo, con la censura burlesca de la capacidad traductora de su rival; y tercero, con la diatriba central contra la pretensión de los carmelitas de que la decisión del rey no sea en ningún caso revocada. A estos niveles conviene añadir algunas de las facetas más discutidas en el debate como la condición de española, la de santa moderna o la del apoyo generalizado o no de las distintas iglesias y universidades al copatronazgo. Y dentro del marco más personal, no deben olvidarse los ataques quevedianos a la pretensión de los carmelitas de influir afectivamente en el rey, al que el fraile carmelita le recuerda las intercesiones de la santa y de sus hijos en sus antecesores. Este aspecto, ya tratado de modo fugaz en su Memorial, adquiere en este escrito un relieve excepcional que no creo pudiera pasar inadvertido ${ }^{16}$.

En el nivel inicial, el primer término que a Quevedo le parece impropio en el texto de fray Pedro es el de la palabra hechicera aplicada a santa Teresa. Quevedo arguye de forma bien diversa que con

16 Utilizo esta expresión de forma figurada, dada probablemente la escasísima, por no decir nula, recepción de este texto. 
Balboa, emplea la ironía, con nota además jocosa: "Y ahora añade una cláusula con palabras harto agraciadas. «Si Santo o Santa se conocen el día de hoy que a lo hechicero haya ganado corazones es Santa Teresa». A lo hechicero, Santa Teresa. Si yo lo juntara, fuera mal sonante y aun se tuviera a herejía". Fray Pedro complementa esta apreciación con lo siguiente: "así se dice entre los propios y extranjeros, y su lenguaje confirma mi verdad, cristianando con el renombre de santa el nombre de hechicera española" (f. 2). La matización "cristianando" parece fruto del recelo del fraile por lo inapropiado de la expresión; sin embargo, lo mantiene, con la consiguiente veta para la censura quevediana.

El segundo es el comentario elogioso de fray Pedro sobre la devoción que provoca la figura de santa Teresa. Quevedo encuentra en una de sus alabanzas a la santa motivo para la burla: se trata de la frase en la que el fraile dice que las imágenes de santa Teresa se hallan "no sólo en los oratorios y aposentos de sus devotos y en los pechos de los que sobreescriben su honestidad con este dechado, sino también en las tiendas de pintores, escultores y plateros" (f. 2v). Quevedo se muestra sarcástico con la idea de que las imágenes de la santa permanezca en las tiendas: si es así, insinúa con complacencia Quevedo, es porque nadie las compra y, por tanto, la santa carece de la devoción de la que el fraile hace alarde.

La exaltación de santa Teresa es motivo para la sutileza irónica de Quevedo en otro ángulo de la diatriba. El ya repetido argumento de la procedencia española de la santa sirve en este caso para burlescos juicios a propósito de expresiones un tanto impropias. La primera es la de llamar a santa Teresa en un mismo parágrafo "conquistadora", "buena hermana" o emplear los términos agente y gajes al tratarse de la devoción de la santa. Con falsa condescendencia, Quevedo disculpará al fraile la asociación entre intercesión y pago por los servicios prestados: "hallóselas acaso, no las estudió devoto"17. Por supuesto, Quevedo saca de contexto las palabras de fray Pedro, como en el primero de los adjetivos, conquistadora, formulado de la manera siguiente: "esta piedad de España, tributaria de su conquistadora santa Teresa" (Memorial que dio a su majestad, f. 3). O en el caso de "buena hermana" que a Quevedo le parece escaso panegírico: "Y acusa con decir «es buena hermana que como tal quiere a España...». Poco es «buena hermana» a quien es soberana y milagrosa Madre y poderosísima auxiliadora". En pasajes posteriores, como añadidos a otro género de acusaciones, Quevedo hará notar la improcedencia de ciertos vocablos, como cuando afea a fray Pedro que diga de una san-

\footnotetext{
${ }^{17}$ Este tipo de censura se repetirá más adelante cuando recrimine a fray Pedro el empleo impropio de la palabra empeños: "Señor, ¿cómo se puede apropiar la palabra empeños a los santos?".
} 
ta que se halla descansada y sobrada: "de quién ha de cobrar España sino de su deudora, y más hallándola tan descansada, tan sobrada, tan rica, tan poderosa con Dios"18.

El ataque de Quevedo al flanco filológico de fray Pedro revela sus inclinaciones en la polémica, porque Quevedo se mofa abiertamente, aunque con apariencia de magisterio, sobre la capacidad traductora del fraile. A propósito de una cita del libro de Ester, fray Pedro traduce:

que en misterioso desvelo dio una noche principio al recuerdo del mal premiado Mardocheo, espía de su seguro y tope de los que conspirando contra su rey, alevosos intentaban su postrera fortuna. Mas como soberano le llevó más la inclinación a honrar su defensor que a solazar su seguro. Sin aguardar consultas de estado, se halló el de la razón en boca de la sinrazón del envidioso Amán, original que vino a ser engañoso a su autor y honroso al fiel Mardocheo. Y los favores, que por prometérselos para sí tantos acumuló Amán, vinieron a ser premio de Mardocheo (f. 4v)

Quevedo le responde con un tipo de ironía inusual: "lo razonado que sigue a estas palabras para mi poco talento es un laberinto de recuerdos, espias, seguros, topes, alevosos, y solazar y acumuló. Yo no lo entiendo: por alabanza lo digo". Pero a continuación realiza un ejercicio de traducción y glosa completo del texto bíblico, aplicado punto por punto a la circunstancia del momento y destinado a convencer al rey, según se desprende del episodio, de "que los reyes honran al que deben honrar y ahorcan al que pide las honras y las aconseja para sí, y más si son con tan delincuentes ceremonias como éstas. Y esto ya se ve cómo es verdad y a quién se dio la honra y a quién el castigo". Es muy evidente que Quevedo conoce bien el terreno que pisa y aprovecha la ocasión para abusar de su preminencia erudita. Fray Pedro emplea esta autoridad de modo muy tangencial, sin concederle especial importancia; Quevedo la agota de manera muy particular. La burla inicial sobre la incompetencia traductora del fraile se convierte en una extensa paráfrasis bíblica con agudas conclusiones sobre el buen gobierno y los buenos consejeros ${ }^{19}$.

18 En esta misma línea de censura habría que incluir la del argumento de la santa moderna. En el Memorial por el patronato de Santiago Quevedo ya reprochaba a fray Pedro el empleo de este argumento: aquí lo vuelve a traer, si bien de forma más discreta. En el punto 32 FRAY PEDRo dirá: "por ser santa menos antigua que otros se puede más codiciar su intercesión, pues por nueva y menos conocida tiene más derecho a que Dios acredite su santidad y su intercesión" (Memorial que dio a su majestad, f. 9). Quevedo rechazará tanto esta condición como la de haber nacido en España, las dos grandes pruebas de la defensa carmelita de santa Teresa como copatrona de España.

${ }^{19}$ Conviene señalar que el siguiente punto del texto quevediano prolonga esta nota irónica, aunque en otro terreno: sólo para quien confronta ambos textos es posible la comprensión de la burla. El argumento de fray Pedro es el siguiente: "Señor, si un acreedor tuviese dos deudores, que el uno debe diez y el otro veinte y 
Este tipo de censura conduce en un pasaje posterior a una más grave advertencia. Se trata del pasaje en el que fray Pedro traduce una parte del episodio bíblico del encuentro de Jesús con la viuda (Lucas 18, 2). El fraile parafrasea una parte - "pero, al ruego de una mujer viuda que le dijo Vindica me Domine de adversario meo, rindió luego audiencia grata y afectos humanos"-, pero Quevedo quiere entender que está traduciendo de forma literal ${ }^{20}$. Y lo hace con particular ironía: "debe de entender no hay en el mundo otra Biblia sino la suya" para luego citar el texto en latín y adoptar una postura inquisidora contra la facilidad con que su opositor traduce libérrimamente el texto bíblico:

el Evangelio dice "y no quería por mucho tiempo", y el autor, contra el texto sagrado, dice "rindió luego audiencia grata, y afectos humanos", que también es contra el evangelio, porque Cristo dijo "mirad lo que dice el juez de la maldad". Y San Agustín de verbis Domini in Lucam Serm. 36. dice deste juez: "Victus taedio non pietate inclinatus. 1. Vencido de la porfía, no inclinado de piedad". Y esto es de fe, porque el Evangelio dice: "Sed quia molesta est mihi haec vidua". Y dice, contra el texto sagrado, el autor "que rindió audiencia grata y afectos humanos", siendo lo contrario, como he probado, fe católica.

Todo ello, sin desperdiciar, en un apunte rápido, la posibilidad, como en el caso anterior, de apurar la analogía propuesta por su adversario: la de que santa Teresa aparezca a los ojos de los lectores como una mujer tan importuna en sus peticiones como la viuda del relato evangélico ${ }^{21}$.

La alteración, o tergiversación como en este caso, del texto de fray Pedro es frecuente en Quevedo, aunque en la mayor parte de los casos no suele ser sustancial. En una de las argumentaciones Quevedo reproduce de forma muy incompleta la frase de fray Pedro. Sólo se atiene a uno de los pilares de la devoción teresiana: "se le debe el título por fundadora de tantos conventos, que ruegan a Dios por la

quisiere ejecutar por los veinte al que debe sólo diez, ¿quién no diría que ejecutar al que debía los veinte y no pidiese veinte al que sólo debe diez?” (f. 5). Quevedo resume burdamente el texto de fray Pedro con estas palabras: "Trae el autor un argumento arismético de acreedores y deudores: en diez y en veinte infiere unas suposiciones". La burla de la competencia argumentativa de su contrario también, como se ve, está presente.

20 De hecho, el texto de FRAY PEDro concluye con la siguiente cláusula, alejada por completo del paso bíblico: "castigando la causa de sus querellas" (Memorial que dio a su majestad, f. $9 \mathrm{v})$.

${ }^{21}$ En este pasaje de fray Pedro se hace una mención que Quevedo pasa por alto porque podría comportar otro género de implicaciones: me refiero a la referencia del fraile, puesta, además, en boca de santa Teresa, a las personas (rey y valido) que directamente estuvieron involucradas en la obtención del patronato: "Juzgad, señor, mi causa y ved si es justo que lo que vos y vuestros primeros ministros me han dado, otros traten de quitar" (Memorial que dio a su majestad, f. 9v). 
salud de su Majestad”. Quevedo contestará a esta cláusula con la idea de que esto no es exclusivo de la santa y tratará de explicar cómo otros santos realizan las mismas funciones. El texto completo de fray Pedro ofrece una más precisa relación de los méritos de la santa y permite comprender mejor la detallada argumentación de Quevedo:

Débela España lo mismo por otro título, que es el de fundadora de tantos conventos, casas de seguro (si en esta vida le hay) donde tantos hijos de la nación, no sólo se salvan sino también la ilustran con ejemplos y doctrinas y tantas buenas hijas que resplandecen como estrellas del firmamento, reformando los unos y las otras las costumbres de España, facilitando la virtud y haciendo perpetua oración por las cabezas de toda su monarquía (f. 3v).

Quevedo contrapone a todo ello las misiones de la milicia santiaguista: "esto le sobra a Santiago con monjas, religiosos y caballeros y hospitales donde sus hijos y hijas atienden a lo activo y a lo contemplativo, a todo estudio, predicación y cátedras, a la guerra y a la caridad, y refugio y alivio de los pobres y enfermos".

El siguiente parágrafo del texto de fray Pedro prolonga este argumento con una expresión que a Quevedo le resultará injusta. Quevedo transcribe: "concurren a un mismo querer España y Santa Teresa en la conquista de herejes, a quien conquistó Santiago con la espada y santa Teresa con la oración". La cita exacta de fray Pedro es:

Junte a esto vuestra majestad otro título, que es concurrir a un mismo querer España y santa Teresa, y al seguimiento de una misma conquista y alcance de una misma victoria de herejes enemigos a quienes postra España con la espada y santa Teresa con la oración (Memorial que dio a su majestad, f. 3v).

La oración del fraile carmelita está alterada y, aunque pueda indicar lo que Quevedo simplifica y resume, la contraposición entre espada y oración no es tan evidente. Quevedo aprovechará esta alteración del texto para arremeter contra quienes ven en Santiago un santo guerrero, desprovisto de espiritualidad. Para ello, aducirá pasajes conocidos de la defensa jacobea, como el sermón de Tomás de Villanueva sobre la intervención de Santiago en otros lugares del mundo o la predicación del padre Orozco en los mismos términos. La extensión de esta refutación no se compadece con el cuidado con el que fray Pedro asume la faceta piadosa de santa Teresa. Da la impresión de una polémica falsamente inventada por Quevedo, por cuanto no en vano, en el número 131 del texto de Balboa de Morgovejo se presenta una contraposición semejante a la propuesta por Quevedo: "Sea pues Santiago nuestro patrón con la espada y con la oración. Sea santa Teresa con sola la oración" (Por la sagrada religión, p. 49). 
Otra de las autoridades aducidas por fray Pedro, también de forma fugaz, es la del pasaje bíblico (Lucas 4, 23) de la resurrección de Lázaro. Fray Pedro propone en su calificación de la santa como "hermana intercesora y patrona" una analogía con las hermanas Marta y María. Quevedo emplea la misma estrategia señalada para la refutación: la de acudir a la fuente evangélica y afinar la correspondencia. De esta manera, parafrasea el pasaje con el recuerdo de que María ponía obstáculos a Cristo para resucitar a su hermano, con los vocablos más cercanos al texto latino: "iam fetet quadriduanus enim est", "le dijo que ya hedía y que era cuatriduano" (Juan 11, 39). Y acaba la diatriba con afirmar, sin explicaciones y con un dejo de suficiencia dialéctica, que ambas hermanas nunca fueron patronas de Lázaro.

El tercer nivel de crítica quevediana toca el núcleo de la discusión polémica: la revocabilidad del decreto. Por ello se vuelve un poco más severo al tratar la transcripción de fray Pedro de la carta del secretario del rey Felipe III, con la que el fraile quería probar que el rezo de santa Teresa ya estaba extendido. Quevedo lo combate con la misma arma: ya que, en efecto, la carta de Jorge de Tovar, fechada el 24 de septiembre de 1618, era más favorable a los intereses de los santiaguistas que a los carmelitas:

su majestad por justas consideraciones me han mandado escribir a v. s. que, no embargante su carta de cuatro de agosto en que trata el rezo de la santa madre Teresa de Jesús y del haberla recibido por patrona el reino juntó en cortes y que así se recibiese en las demás de esta corona es servido que cuanto al rezo sea conforme al breve de su santidad, guardando las reglas del breviario y en cuanto al recibirla por patrona y fiestas que se habían mandado hacer, cese todo hasta que su majestad mande otra cosa ${ }^{22}$.

En este terreno Quevedo vuelve al tema principal de su diatriba contra el doctor Balboa: el de la posibilidad de que el rey revoque la decisión adoptada. En este caso, Quevedo reúne al conjunto de sus adversarios para confrontarlos, si bien se centra de modo especial en las palabras del autor de otro de los papeles más importantes de la polémica, el escrito con toda probabilidad por el obispo de Córdoba titulado Justa cosa ha sido eligir por patrona de España y admitir por tal a santa Teresa, que insiste, por encima de las decisiones reales e incluso de las pontificias, que el patronato de santa Teresa sigue siendo válido ${ }^{23}$. Esta refutación quevediana se complementa con el rechazo

${ }^{22}$ Lo más paradójico es que FRAY PEDRo transcribe la carta: la referencia que incluyo de ahí procede (Memorial que dio a su majestad, f. 7).

${ }^{23}$ Casi al término de este papel se expresa el obispo: "aunque el papa revocase el dicho Breve, quedaría válido el patronato" (Justa cosa ha sido eligir por patrona de España y admitir por tal a santa Teresa, f. 7). 
pleno a la afirmación de fray Pedro de que "a la devoción de vuestra majestad han mostrado su lealtad tantas ciudades, tantas iglesias catedrales, y colegiales, tantas religiones y las insignes universidades, la Atenas del mundo Salamanca, y sus dos ojos, Alcalá" (Memorial que dio a su majestad, f. 13). Quevedo, apoyado en los cambios de postura de algunos prelados al respecto, contesta al fraile con notas más particulares sobre la actitud de la iglesia ante la nueva situación:

No cuenta el autor en cuán excesivo número exceden las que no sólo no la han admitido, pero escrito informaciones y hecho contradicción y que en decir que Alcalá la ha recibido engaña a Vuestra Majestad. Y es de advertir que entre las pocas iglesias que la recibieron la de Badajoz ha impreso doctísimamente su arrepentimiento, pidiendo se revoque este compatronato, cosa de grande horror.

Quevedo refleja, en el último tramo de su respuesta, el paulatino ocaso de la pretensión del patronato de santa Teresa, aunque hubo que esperar hasta 1630 para que las tesis santiaguistas tuvieran cumplida satisfacción.

Fuera de este orden de críticas hacia el uso inadecuado de vocablos en la persona de la santa, se hallan otras objeciones de mayor interés político. Uno de los parágrafos más importantes del texto de fray Pedro que Quevedo recoge es el pasaje en el que el fraile recuerda al rey Felipe IV los beneficios que la santa ha reportado a sus inmediatos antepasados. Se trata de un pasaje, comentado rápidamente en el Memorial, que aquí adquiere una enjundia muy especial. Fray Pedro sostiene que santa Teresa ha beneficiado a los reyes, bien directamente, bien a través de uno de sus seguidores:

en el reconocimiento que España debe a santa Teresa entra vuestra majestad también, que como cabeza y parte principal le cabe la suya por sí mismo y su glorioso abuelo, si bien beneficiados de la santa por diferente camino, uno en vida, y otro en muerte, uno por medio de la santa y otro por medio de sus hijos (Memorial que dio a su majestad, f. 4).

Fray Pedro cuenta en primer lugar cómo transcurrió el purgatorio de Felipe II y cómo la santa intercedió por él para librarle de ese lugar. Fray Pedro indica que gracias al novenario sólo estuvo ocho días y que al noveno logró subir a los cielos. Quevedo arremete con especial violencia al asegurar que ni una sola hora estuvo en el purgatorio Felipe II, que es comentario audaz sin duda, pero aún más acompañado de expresiones en este contexto no demasiado apropiadas: 
y para decir que salió de purgatorio al otavo día, que yo hasta ahora en fe de su justicia y virtudes y sufragios ${ }^{24}$ y trabajos creía, que una hora no había estado en el purgatorio aquella generosa alma de vuestro grande abuelo, no era menester bambolearle la salvación a raíz de canonizado y luego conjeturarle purgatorio.

Por si el argumento de la deuda contraída por los Austrias con santa Teresa pudiera limitarse a Felipe II, fray Pedro recuerda al monarca que el padre carmelita Francisco de Jesús ya había intercedido por su padre Felipe III para que pudiera tener descendencia, por lo tanto, para que Felipe IV pudiera nacer. La intercesión se llevó a cabo a cambio de unos seis mil ducados, tal y como el fraile carmelita asegura. Todo este relato va encaminado a forzar a Felipe IV a sentirse obligado con la santa con el argumento casi irrefutable de que el monarca le debe, en palabras de fray Pedro, "a la Santa el ser y vida de que gozáis". Las palabras de fray Pedro ya habían escandalizado a Quevedo en el Memorial, pero aquí Quevedo acusa, ya sin asomo de sarcasmo, a los frailes carmelitas de algo peor que persuasión interesada: "esto (así lo dice el memorial) se debe al hermano Francisco del niño Jesús, con quien dice que se celebró pacto por el nacimiento de Vuestra Majestad por seis mil ducados. Grandes son estas revelaciones y de las que el Concilio manda que se califiquen primero, que se impriman o hagan publicar". Lo que el Concilio (de Trento) manda calificar, imprimir y publicar son los abusos

que se han originado de la superstición, ignorancia, irreverencia o de otra cualquiera causa, por las muchas corruptelas de los lugares y provincias en que se cometen. Para ellas, las reglas del Concilio mandan a todos los obispos que cada uno note todos estos abusos en su iglesia y los haga presentes en el primer concilio provincial para que, conocidos y calificados por los otros obispos se delaten inmediatamente al sumo Pontífice Romano... y de este modo se reparta a todos los fieles, piadosa, santa e íntegramente el tesoro de las santas indulgencias.

En ese caso, la acusación de Quevedo es muy grave, ya que se trata de superstición, ignorancia e irreverencia. A pesar de ello, Quevedo deja para el final de la severa denuncia una nota más insidiosa, al subrayar que la intercesión por la vida de Felipe IV se debe al padre Francisco de Jesús y no a santa Teresa, por lo que el dinero recibido debería haber ido a manos del religioso y no a las de la casa de

${ }^{24}$ Justicia y virtudes se deben a Felipe II; debían de ser suficientes para alcanzar el cielo; sin embargo y, a pesar de la alabanza, parecen obligatorios los sufragios, que, según definición del Dic. Aut., "ayudan y minoran las penas que merecen por sus culpas o las satisfacen". No se pueden olvidar al respecto los comentarios escasamente elogiosos de Quevedo hacia Felipe II en El chitón de las tarabillas. 
los carmelitas: "la obligación jurídica corre en Vuestra Majestad respeto del dicho siervo de Dios, que la gloriosa Santa no ha menester para nada valerse de los méritos de sus hijos".

\section{Conclusión}

Suposiciones jurídicas, políticas y piadosas son las que Quevedo rebate en Su espada por Santiago. Refuta las primeras con el texto de Balboa como referencia, en un esfuerzo básico de hacer ver más las contradicciones de Balboa que de discutir uno a uno sus planteamientos. El fuste intelectual del papel de Balboa sólo pudo encontrar en sus incoherencias los flancos débiles para el ataque. Y por ello utilizará a Balboa contra Balboa, en un único parecer: el de demostrar que donde ayer postulaba la revocabilidad de las decisiones reales hoy rechaza cualquier propósito que la altere. Para las piadosas y políticas eligió como principal opuesto a un fraile carmelita de expresión coloquial, capaz de arrojarse a la polémica con armas tan dispares como propicias para la censura. Aunque las jurídicas parecen las más importantes desde un punto de vista funcional, las otras dos aparecen más desarrolladas por Quevedo: quizá porque el litigio desde el punto de vista jurídico se limitaba a los términos en los que lo formulaba Balboa de Morgovejo en torno a la responsabilidad del rey, del reino y del pontífice en el copatronato y Quevedo admitía de modo implícito su escasa competencia en ese terreno; y, sobre todo, porque fray Pedro tocaba aspectos que eran de más eficaz dialéctica para el Quevedo más ejercitado en lo satírico que en las informaciones de derecho que contendían en la polémica. De todas maneras, para su infortunio, sus beligerantes esfuerzos fueron baldíos: hallaron en el acuse de recibo de una estafeta sin abrir la respuesta. Su espada por Santiago quedó clavada para siempre en la puerta cerrada de la audiencia del Conde-Duque de Olivares ${ }^{25}$.

\section{Manuel Ángel Candelas Colodrón Universidade de Vigo}

\footnotetext{
25 El doctor Álvaro de Villegas, secretario del Conde-Duque, así se lo advierte a Quevedo en carta fechada el 18 de mayo de 1628. Comienza: "Recibí la de vuestra merced y el pliego que venía con ella no conviene darle, porque ni el conde está bien en el caso ni tienen razón los que le contradicen"; y termina: "He dicho a vuestra merced brevemente lo que se me ofrece y vuelvo a vuestra merced el pliego cerrado como me lo envió" (Epistolario completo, pp. 194-195).
} 